\title{
Paracetamol degradation and kinetics by advanced oxidation processes (AOPs): Electro-peroxone, ozonation, goethite catalyzed electro-fenton and electro-oxidation
}

\author{
Hazal Öztürk ${ }^{1}$, Sibel Barışçı ${ }^{2,3^{\dagger}}$, Ozge Turkay ${ }^{3,4}$ \\ ${ }^{1}$ Kocaeli University, Environmental Engineering Department, 41380, Umuttepe, Kocaeli, Turkey \\ ${ }^{2}$ Temple University, Collage of Engineering, Water and Environmental Technology (WET) Center, 1947 N $12^{\text {th }}$ St., Philadelphia, PA, 19122 \\ ${ }^{3}$ Cebze Technical University, Environmental Engineering Department, 41400, Gebze, Kocaeli, Turkey \\ ${ }^{4}$ University of Health Sciences, Institute of Health Science, Department of Biotechnology, Istanbul, Turkey
}

\begin{abstract}
The advanced oxidation of paracetamol (PCT), frequently used analgesic, promoted by electro-oxidation (EOX), goethite catalyzed electro-Fenton (GEF) with goethite, ozonation and electro-peroxone (E-peroxone) was investigated. The degradation efficiency of the processes was evaluated considering the decay of PCT versus time. All the processes showed pseudo-first order character for PCT degradation. $k_{\mathrm{obs}}$ values, at optimum conditions for an individual process, were defined as $0.0022,0.0029,0.0870$ and $0.1662 \mathrm{~min}^{-1}$ for EOX, GEF, ozonation and E-peroxone processes, respectively. Where EOX and GEF processes showed poor degradation efficiencies, novel E-peroxone process provided complete removal of PCT. The degradation of the PCT would mostly occur by $\mathrm{OH}^{\circ}$ and molecular $\mathrm{O}_{3}$ due to the higher rate constants achieved at E-peroxone and ozonation Conversely, with lower $k_{\mathrm{obs}}$ values gained at EOX, hydroxyl radicals would not contribute noticeably to the PCT degradation. In GEF process, due to relatively lower $\mathrm{OH}^{*}$ production rate, lower $k_{\mathrm{obs}}$ values were obtained for the degradation of PCT. The formation of reaction intermediates, aromatics and carboxylic acids, was also determined in this study.
\end{abstract}

Keywords: Electro-oxidation, Electro-peroxone, Goethite catalyzed electro-Fenton (GEF), Ozonation, Paracetamol

\section{Introduction}

Pharmaceuticals have received great consideration as aquatic pollutants due to the existence of a large number of anti-inflammatories, antibiotics, analgesics, beta-blockers, lipid regulators and anti-psychotics at concentration levels of $\mathrm{ng} \mathrm{L}^{-1}$ to $\mathrm{mg} \mathrm{L}^{-1}$ in municipal wastewater effluents, surface water, groundwater, sea water and even in drinking water [1-4]. The existence of pharmaceuticals in those water matrices causes aquatic toxicity due to their non-biodegradable structure. Besides, it is not possible to remove these kinds of chemicals by conventional treatment methods [5, 6]. Bearing in mind that thousands of tons of pharmaceutical constituents are manufactured and used annual in human and veterinary medicine, extensive amounts of these constituents can reach the aquatic environment, mainly by receiving wastewater from treatment plants because of their inadequate removal.
Paracetamol (PCT) ( $N$-(4-hydroxyphenyl)acetamide) is a commonly used analgesic drug which has been found at concentrations of 7.4-45.6 $\mu \mathrm{g} \mathrm{L}^{-1}$ in wastewater treatment plant (WWTP) influent in Czech Republic [3], 0.11-11.31 $\mu \mathrm{g} \mathrm{L}^{-1}$ in WWTP effluent, 10.6-72.3 ng $\mathrm{L}^{-1}$ in surface water and up to $210.1 \mathrm{ng} \mathrm{L}^{-1}$ in drinking water in France [7].

Accordingly, there is increasing interest to develop efficient treatment processes for controlling the occurrence of pharmaceutical pollutants in aquatic bodies. Advanced oxidation processes (AOPs) have been used widely to remove pharmaceutical compounds such as ozonation [8-11], ferrate (VI) [12, 13], photocatalysis [14-16] and electrochemical oxidation $[17,18]$. Chemical oxidation with ozone is an efficient technology for the removal of organic pollutants, but the performance is often not strong enough due to its selectivity to remove some target pollutants in a realistic time and cost frame. Electro-oxidation (EOX), in some cases, is an effective treatment
This is an Open Access article distributed under the terms of the Creative Commons Attribution Non-Commercial License (http://creativecommons.org/licenses/by-nc/3.0/) which permits unrestricted non-commercial use, distribution, and reproduction in any medium, provided the original work is properly cited.

Copyright (C) 2021 Korean Society of Environmental Engineers
Received September 18, 2019 Accepted March 31, 2020

† Corresponding author

Email: sibel.barisci@temple.edu

Tel: +1 (215) 268-8395

ORCID: 0000-0003-4229-0408 
for the degradation of biorefractory pollutants. During EOX, pollutants can be degraded by the electron transfer at the anode surface or the reaction with $\mathrm{OH}^{\bullet}$ formed from oxidation of water in acid and neutral media or $\mathrm{OH}^{-}$at $\mathrm{pH} \geqslant 10$.

Another AOP for wastewater treatment is commonly used Fenton process. The oxidative potential of $\mathrm{H}_{2} \mathrm{O}_{2}$ can be improved in acidic medium by adding of $\mathrm{Fe}^{2+}$ catalyst. According to the classical Fenton's reaction, $\mathrm{OH}^{\bullet}$ are produced in the solution via the reaction between $\mathrm{H}_{2} \mathrm{O}_{2}$ and $\mathrm{Fe}^{2+}$ [19]. In recent years, instead of adding $\mathrm{H}_{2} \mathrm{O}_{2}$ externally, Fenton reaction has been conducted by the electrochemical approach [20, 21]. The use of carbon-based cathodes with high $\mathrm{H}_{2} \mathrm{O}_{2}$ production potential has attracted great attention in electro-Fenton (EF) process [22, 23].

The reaction of $\mathrm{H}_{2} \mathrm{O}_{2}$ with $\mathrm{O}_{3}$, i.e. peroxone process, is one of the AOPs that delivers $\mathrm{OH}^{\bullet}$ formation in aqueous solution. High reactivity of $\mathrm{OH}^{\bullet}$ allows effective pollutant degradation. As an innovative process, peroxone reaction can be conducted by the electrochemical approach and that is called electro-peroxone (E-peroxone). The E-peroxone process is a simple combination of ozonation and electro-oxidation. In the E-peroxone process, while a small amount of feeding $\mathrm{O}_{2}$ is transformed to $\mathrm{O}_{3}$ by ozone generator, the inconvertible amount of $\mathrm{O}_{2}$ is sparged into the reactor directly. Carbonbased cathode is used to convert the excessive $\mathrm{O}_{2}$ to $\mathrm{H}_{2} \mathrm{O}_{2}$ electrochemically. The electro-generated $\mathrm{H}_{2} \mathrm{O}_{2}$ then reacts with the sparged $\mathrm{O}_{3}$ to form $\mathrm{OH}^{\bullet}$, which can remove refractory pollutants in wastewater efficiently [24]. However, in some cases, molecular $\mathrm{O}_{3}$ can be more effective species instead of $\mathrm{OH}^{\bullet}$ on the degradation of pollutants. The mechanism needs to be investigated in detail.

This work deals with a detailed study of the degradation of PCT under E-peroxone, ozonation, EF and EOX processes. As far as we know, this work reports for the first time the comparison of four different AOPs on the degradation efficiency of PCT. In this study, the effect of some experimental parameters for an individual AOPs were investigated. After the determination of the optimum conditions for each process separately, the kinetics of four different AOPs were compared for the degradation of PCT.

\section{Material and Methods}

\subsection{Chemicals}

Paracetamol Reference Standard was supplied from European Pharmacopoeia and sodium sulphate $(\geq 99.99 \%$, trace metals basis) was purchased from Sigma-Aldrich. The $\mathrm{pH}$ was adjusted by 0.1 $\mathrm{M} \mathrm{H}_{2} \mathrm{SO}_{4}$ and $0.1 \mathrm{M} \mathrm{NaOH}$ solutions. Stock solutions for the treatment procedures (100 $\mathrm{mg} \mathrm{L}^{-1} \mathrm{PCT}$ ) were prepared daily in high-quality pure water using the Millipore Water Purification System and stored at $4^{\circ} \mathrm{C}$.

\subsection{Experimental Set-up for E-peroxone, Ozonation, Electro-Fenton and Electro-oxidation Treatment of PCT}

All experiments were conducted in an undivided cell with a volume of $2 \mathrm{~L}$. The anode was Pt, and the cathode was carbon-polytetrafluoroethylene (PTFE) with the geometric areas of 15 and $25 \mathrm{~cm}^{2}$, respectively. Electrodes were located in the cell with a $0.2 \mathrm{~cm}$ gap, and initial concentration of $100 \mathrm{mg} \mathrm{L}^{-1}$ PCT including $\mathrm{Na}_{2} \mathrm{SO}_{4}$ as supporting electrolyte solution was added into the cell. The solution was stirred with a magnetic stirrer at $400 \mathrm{rpm}$ during the reaction time. The current was kept constant at selected levels in E-peroxone, GEF and EOX processes. During each run, samples were taken from the supernatant layer at different time intervals and then rapidly filtered for further analysis.

During ozonation treatment, $\mathrm{O}_{3}$ from pure $\mathrm{O}_{2}$ gas (99.9\%) was produced via an ozone generator (YEOJEN, OTRIO MT-20). The effluent $\mathrm{O}_{3}$ concentration in the ozone generator was adjusted by changing the ozone flow rate. The ozone generator effluent was then sparged into the cell at constant flow rates of 0.5 and $5 \mathrm{~L}$ $\min ^{-1}$.

EOX and E-peroxone treatment were carried out under galvanostatic conditions using GW Instek PSP-405 Programmable DC power supply. The EOX was in the progress by turning on the DC power supply while the ozone generator was off. DC power supply and the ozone generator were both turned on simultaneously for E-peroxone treatment. GEF process was conducted at the same conditions with EOX with the addition of appropriate amount of goethite powder as an iron source to PCT solution.

\subsection{Instruments and Analytical Methods}

The PCT concentrations were determined by high-performance liquid chromatography (HPLC, Shimadzu) equipped with an Inertsil ODS-3 C18 column (4.6 mm x $250 \mathrm{~mm}$ ) and a UV detector where the wavelength set at $254 \mathrm{~nm}$. Acetonitrile/water (v/v) at 58/42, with the addition of $2 \mathrm{~mL}$ concentrated $\mathrm{H}_{3} \mathrm{PO}_{4}$ per liter of solution was used as the mobile phase for PCT analysis and the injection volume was $25 \mu \mathrm{L}$. The flow rate was $0.3 \mathrm{~mL} \mathrm{~min}^{-1}$.

Electro-generated $\mathrm{H}_{2} \mathrm{O}_{2}$ and aqueous $\mathrm{O}_{3}$ were monitored using a probe (JUMO GmbH \& Co., Germany) during each process. The $\mathrm{OH}^{\bullet}$ concentration was analyzed as stated by terephthalic acid (TA) cumulative protocol as described elsewhere [25].

The $\mathrm{Fe}^{2+}$ and $\mathrm{Fe}^{3+}$ contents from dissolved goethite were measured using Dr. Lange cuvette tests in combination with a spectrophotometer (Hach DR-5000).

Regression coefficients $\left(\mathrm{R}^{2}\right)$ and $k$ values were determined using OriginPro 8 software.

\section{Results and Discussion}

\subsection{The Degradation of Paracetamol by Electro-oxidation}

The degradation of the PCT solution by EOX at an initial $\mathrm{pH}$ of $6.8 \pm 0.2$ was evaluated at different applied current values: 0.02 , $0.1,0.7$ and $2 \mathrm{~A}$. According to the results, increasing applied current enhances the degradation of PCT. However, the degradation rate was very low, even at the highest applied current. The residual concentration of PCT was $89.4 \mathrm{mg} \mathrm{L}^{-1}$ with only $12.9 \%$ removal efficiency.

The reaction kinetics have been studied and according to the $\mathrm{R}^{2}$ values (data not shown), the degradation of PCT by EOX process was fitted to the pseudo-first order rate law. The rate expression for the reaction of PCT with $\mathrm{OH}^{\bullet}$ may be expressed with the following equation: 

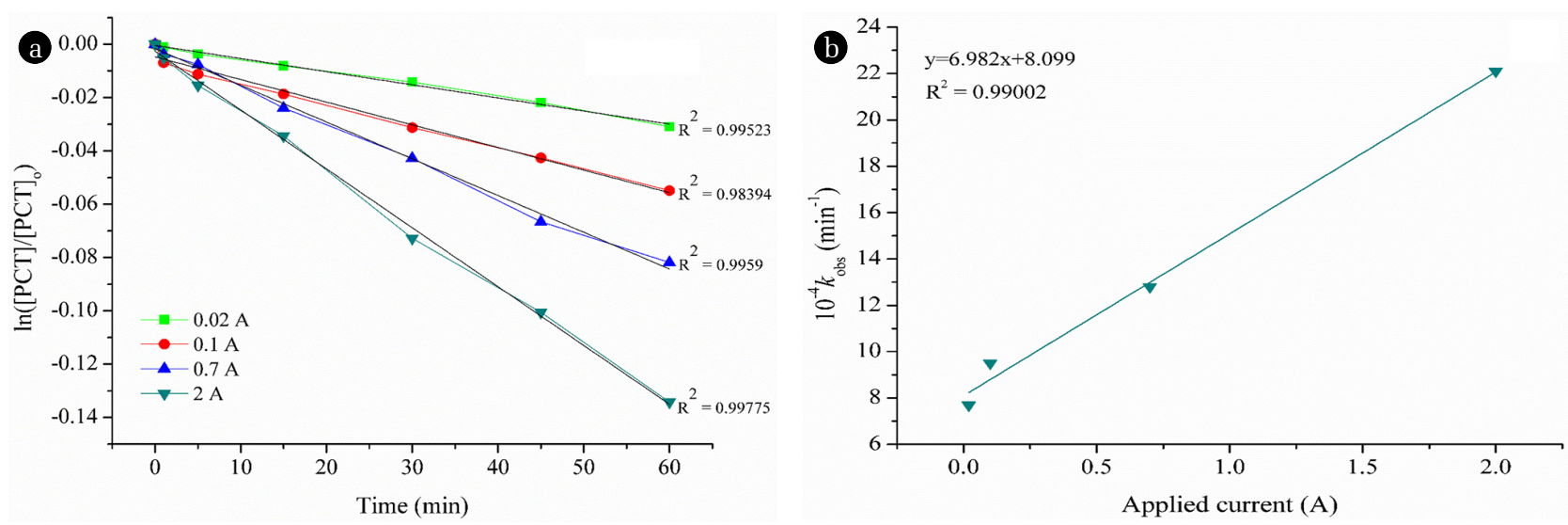

Fig. 1. Determination of reaction order for PCT degradation by EOX: (a) Plot of $\ln [\mathrm{PCT}] /[\mathrm{PCT}]_{\mathrm{o}}$ vs. process time at different applied current values; and (b) Linearity between measured pseudo-first-order kinetic constants (kobs, $\mathrm{min}^{-1}$ ) in terms of applied current values. Reaction conditions: $[\mathrm{PCT}]_{\mathrm{o}}=100 \mathrm{mg} \mathrm{L}^{-1}$, initial $\mathrm{pH}=6.8 \pm 0.2, \mathrm{~T}=25^{\circ} \mathrm{C}$.

$$
-\mathrm{d} \frac{[\mathrm{PCT}]}{[\mathrm{PCT}]_{o}}=k_{\text {app }}[\mathrm{PCT}]^{m}\left[\mathrm{OH}^{\bullet}\right]^{n}
$$

where [PCT] and $\left[\mathrm{OH}^{\bullet}\right]$ are the PCT and $\mathrm{OH}^{\bullet}$ concentrations, $\mathrm{m}$ and $\mathrm{n}$ are the orders of the reaction with respect to the concentrations of PCT and $\mathrm{OH}^{\bullet}$, respectively, and $k_{\text {app }}$ is the apparent rate constant. The kinetic studies were investigated under pseudo-first order conditions with different applied current values. Eq. (1) can be rewritten as:

$$
-\mathrm{d} \frac{[\mathrm{PCT}]}{[\mathrm{PCT}]_{o}}=k_{o b s}[\mathrm{PCT}]^{m}
$$

where $k_{\mathrm{obs}}=k_{\mathrm{app}}\left[\mathrm{OH}^{\bullet}\right]^{\mathrm{n}}, k_{\text {obs }}\left(\mathrm{s}^{-1}\right)$ is the pseudo-first-order kinetic constant. The degradation of PCT followed the pseudo-first-order kinetics within the studied time scales at a given applied current value as demonstrated in Fig. 1a. For a constant initial concentration of PCT (100 mg L ${ }^{-1}$ ), different values of $k_{\text {obs }}$ were determined from the slopes of linear plots at various applied currents (Fig. 1(a)). The value of $k_{\mathrm{obs}}$ increased linearly $\left(\mathrm{R}^{2}=0.9998\right)$ as applied current values were increased from 0.02 to 2 A (Fig. 1(b)), demonstrating a first-order dependence of the reaction on $\mathrm{OH}^{\bullet}$. Accordingly, the reaction between PCT and $\mathrm{OH}^{\bullet}$ was the second order in total and first order regarding each reactant. Consequently, the rate expression for the degradation of PCT by EOX could be described as:

$$
-\mathrm{d} \frac{[\mathrm{PCT}]}{[\mathrm{PCT}]_{o}}=k_{o b s}[\mathrm{PCT}]=k_{\text {app }}[\mathrm{PCT}]\left[\mathrm{OH}^{*}\right]
$$

\subsection{The Degradation of Paracetamol by Goethite Catalyzed Electro-Fenton (GEF)}

The degradation of the PCT by GEF process has been conducted at constant applied current of $0.3 \mathrm{~A}$. As an iron source, $0.5 \mathrm{~g} \mathrm{~L}^{-1}$ goethite was added for each experiment. Three different initial
$\mathrm{pH}$ values (3.0, 6.8 and 10.0) have been studied in order to understand if alkaline $\mathrm{pH}$ values provide better conditions or not for PCT degradation by GEF process. The results were given in Fig. 2.

As is seen in Fig. 2, acidic $\mathrm{pH}$ value provided more efficient and faster degradation for PCT. The concentration decays for PCT were analyzed according to the kinetic models related to different reaction orders. The best linear plot with regression coefficients of $0.999,0.997$ and 0.994 at $\mathrm{pH}$ values of 3.0, 6.8 and 10.0, respectively, were only found when they were fitted to a pseudo first-order model. In literature, Fenton oxidation has been usually modeled using pseudo-first order and pseudo second order kinetics in some cases. Pseudo first-order rate constants $\left(k_{\mathrm{obs}}\right)$ of 0.00290 , 0.00107 and $0.00170 \mathrm{~min}^{-1}$ were gained for PCT degradation by the GEF process at $\mathrm{pH}$ 3, 6.8 and 10, respectively. A study indicates that PCT degradation by EF process followed pseudo-first order kinetic model with rate constant of $0.6718 \mathrm{~min}^{-1}$ [26]. Even though

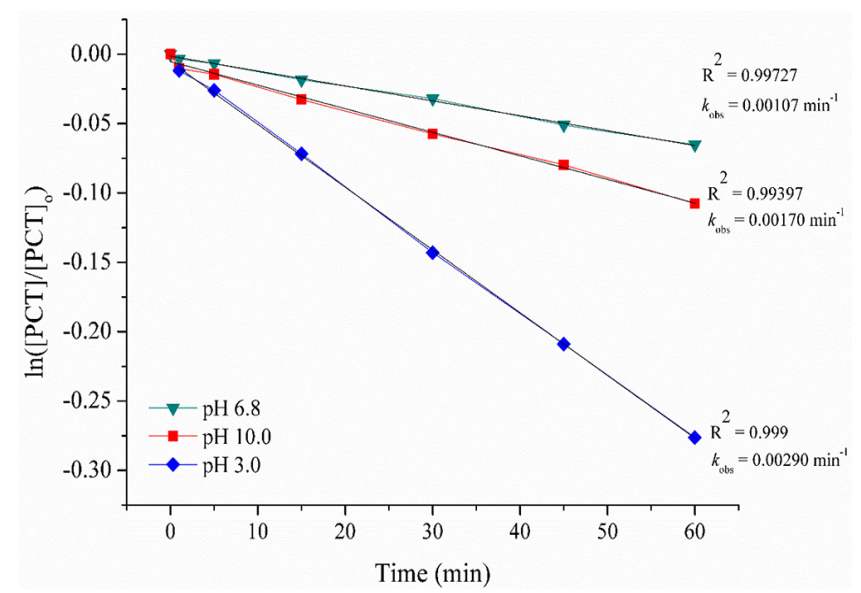

Fig. 2. Determination of reaction order and pseudo-first-order kinetic constants $\left(k_{\text {obs }}, \mathrm{min}^{-1}\right)$ for PCT degradation by GEF: a plot of $\ln [\mathrm{PCT}] /[\mathrm{PCT}]_{\mathrm{o}}$ vs. process time at different $\mathrm{pH}$ values. Reaction conditions: $[\mathrm{PCT}]_{\mathrm{o}}=100 \mathrm{mg} \mathrm{L}^{-1}$, applied current $(I)=0.3 \mathrm{~A}$, goethite concentration $=0.5 \mathrm{~g} \mathrm{~L}^{-1}, \mathrm{~T}=25^{\circ} \mathrm{C}$. 
this value was much higher than we gain in our study, the authors used only $5 \mathrm{mg} \mathrm{L}^{-1}$ PCT concentration. Another study indicated that pseudo-first order rate constant of PCT degradation was found as $0.0624 \mathrm{~min}^{-1}$ for UV assisted EF process [27]. $\mathrm{t}$ is known that acidic $\mathrm{pH}$ values provide more effective results in GEF process as higher $\mathrm{pH}$ values increase $\mathrm{Fe}(\mathrm{OH})_{3}$ formation and precipitation. This may cause fouling of electrode surface and prevent $\mathrm{Fe}^{2+}$ regeneration [28]. Accordingly, optimum $\mathrm{pH}$ value was found to be 3.0 for GEF process which agreed with previous studies $[28,29]$.

GEF reaction involves three key reactions as (1) the formation of $\mathrm{H}_{2} \mathrm{O}_{2}$ from oxygen on the cathode surface (Eq. (4)), (2) the generation of $\mathrm{OH}^{\bullet}$ via the reaction between $\mathrm{H}_{2} \mathrm{O}_{2}$ and $\mathrm{Fe}^{2+}$ (Eq. (5)), and (3) the degradation of target pollutant by the $\mathrm{OH}^{\bullet}$ (Eq. (6)). This is confirmed by other researchers [30, 31].

$$
\begin{gathered}
\mathrm{O}_{2}+2 \mathrm{H}^{+}+2 \mathrm{e}^{-} \stackrel{k_{1}}{\rightarrow} \mathrm{H}_{2} \mathrm{O}_{2} \\
\mathrm{Fe}^{2+}+\mathrm{H}_{2} \mathrm{O}_{2} \stackrel{k_{2}}{\rightarrow} \mathrm{Fe}^{3+}+\mathrm{OH}^{\bullet}+\mathrm{OH}^{-} \\
\mathrm{OH}^{\bullet}+[\mathrm{PCT}] \stackrel{k_{3}}{\rightarrow} \text { products }
\end{gathered}
$$

PCT can be degraded by formed $\mathrm{OH}^{\bullet}$ in electroFenton reaction, thus the reaction rate can be expressed by Eq. (7);

$$
-\mathrm{d} \frac{[\mathrm{PCT}]}{\mathrm{dt}}=k_{3}[\mathrm{PCT}]\left[\mathrm{OH}^{\bullet}\right]
$$

Here, $k_{3}\left[\mathrm{OH}^{\bullet}\right]$ represents $k_{\mathrm{obs}}$ values. Since $\mathrm{OH}^{\bullet}$ production rate is a key factor for PCT degradation by GEF process, the reaction rate can also be written considering $\mathrm{OH}^{\bullet}$ production and consumption rate. The pseudo first-order based on Eq. 7 can be defined for this process as the basic approach. From another point of view, $\mathrm{OH}^{\bullet}$ may react with $\mathrm{Fe}^{2+}\left(k_{4}\right), \mathrm{H}_{2} \mathrm{O}_{2}\left(k_{5}\right)$ and $\mathrm{Fe}^{3+}\left(k_{6}\right)$ as well [32] in addition to the above reactions $\left(k_{1}, k_{2}\right.$ and $\left.k_{3}\right)$. Also, the produced $\mathrm{H}_{2} \mathrm{O}_{2}$ may react with the target pollutants $\left(k_{7}\right)$. However, electro-generated $\mathrm{H}_{2} \mathrm{O}_{2}$ mainly reacts with $\mathrm{Fe}^{2+}$ to form $\mathrm{OH}^{\bullet}$ and the concentration of $\mathrm{Fe}^{3+}$ can be negligible compared to $\mathrm{Fe}^{2+}$ (see Fig. SM-1). This means $k_{6}$ and $k_{7}$ may not be considered. In this case, it may be assumed that $\mathrm{OH}^{\bullet}$ production and consumption rate can be described as:

$$
\begin{aligned}
-\mathrm{d} \frac{\left[\mathrm{OH}^{\bullet}\right]}{[\mathrm{dt}]}= & k_{2}\left[\mathrm{H}_{2} \mathrm{O}_{2}\right]\left[\mathrm{Fe}^{2+}\right]-k_{4}\left[\mathrm{OH}^{\bullet}\right]\left[\mathrm{Fe}^{2+}\right]- \\
& k_{5}\left[\mathrm{OH}^{\bullet}\right]\left[\mathrm{H}_{2} \mathrm{O}_{2}\right]-k_{3}\left[\mathrm{OH}^{\bullet}\right][\mathrm{PCT}]
\end{aligned}
$$

In Eq. (8), $k_{5}$ can be negligible to simplify the equation, because $k_{5}$ was smaller than $k_{4}$ according to the previous study [33]. Besides, the concentration of $\mathrm{OH}^{\bullet}$ is constant at a low level and $\mathrm{d}\left[\mathrm{OH}^{\bullet}\right] / \mathrm{dt}$ will approach zero concerning steady state approximation. Accordingly, Eq. (7) can also be written as:

$$
-\mathrm{d} \frac{[P C T]}{[\mathrm{dt}]}=k_{3} \frac{k_{2}\left[\mathrm{Fe}^{2+}\right][P C T]}{k_{4}\left[\mathrm{Fe}^{2+}\right]+k_{3}[\mathrm{PCT}]}\left[\mathrm{H}_{2} \mathrm{O}_{2}\right]
$$

Consequently, the rate of PCT degradation becomes a function of the PCT, $\mathrm{H}_{2} \mathrm{O}_{2}$ and $\mathrm{Fe}^{2+}$ concentrations.
Table 1. Experimental and Calculated Parameters of Intraparticle Diffusion Kinetic Model for PCT Degradation by GEF Process at Different $\mathrm{pH}$ Values

\begin{tabular}{lccc}
\hline Parameter & pH 3 & pH 6.8 & pH 10 \\
\hline Experimental $\mathrm{q}_{\mathrm{e}}\left(\mathrm{q}_{\mathrm{e}(\mathrm{exp})}\right)\left(\mathrm{mg} \mathrm{g}^{-1}\right)$ & 135.48 & 26.76 & 39.28 \\
Calculated $\mathrm{q}_{\mathrm{e}}\left(\mathrm{q}_{\mathrm{e}(\mathrm{cal})}\right)\left(\mathrm{mg} \mathrm{g}^{-1}\right)$ & 137.15 & 25.68 & 38.65 \\
$\mathrm{R}^{2}$ & 0.998 & 0.995 & 0.999 \\
$k_{i p}\left(\mathrm{mg} / \mathrm{g} \mathrm{min}^{-1 / 2}\right)$ & 17.26 & 3.42 & 5 \\
$\mathrm{C}$ & 3.4532 & 0.7981 & 0.0899 \\
\hline
\end{tabular}

Adsorption kinetics were also evaluated for the degradation of PCT during GEF process. The experimental data were fitted to the intraparticle diffusion model which is represented by the following Weber and Morris equation:

$$
q_{t}=k_{i p} t^{1 / 2}+C
$$

where, $\mathrm{q}_{\mathrm{t}}$ is the amount of absorbed pollutant (mg/g), $k_{\mathrm{ip}}(\mathrm{mg} / \mathrm{g}$ $\min ^{-1 / 2}$ ) is the rate constant, and $\mathrm{C}$ is the intercept. Accordingly, the value of $k_{\mathrm{ip}}$ can be estimated from the slope of the plot $\mathrm{q}_{\mathrm{t}}$ versus $\mathrm{t}^{1 / 2}$ and $\mathrm{q}_{\mathrm{e}}$ can be calculated from the equation ( $\mathrm{q}_{\mathrm{e}}$ (cal)). The experimental data were also fitted to other adsorption kinetic models such as pseudo-first order, pseudo-second order, Elovich kinetic model, and Bangham's pore diffusion model, but the correlation coefficients obtained (data not shown) were very unfavorable. In contrast, as seen by the linear plots of the intraparticle diffusion model for all $\mathrm{pH}$ values given in supplementary material (Fig. SM-2), there is a good fitting of the experimental results to the model. Indeed, as indicated in Table 1, the correlation coefficients are higher than 0.99 and the experimental and calculated $q_{e}$ values

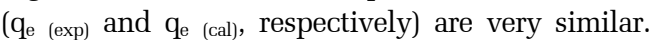

It can be said that PCT adsorption onto goethite was diffusion controlled since intraparticle diffusion model agrees well with the experimental data (the plot of $\mathrm{q}_{\mathrm{t}}$ against $\mathrm{t}^{1 / 2}$ was linear for all $\mathrm{pH}$ values) and intraparticle diffusion was the only rate-limiting step. Also, the adsorption process was faster in $\mathrm{pH} 3$ compared to $\mathrm{pH}$ 6.8 and 10 as expected.

\subsection{The Degradation of Paracetamol by Ozonation}

$\mathrm{OH}^{\bullet}$ can be generated through the reaction between $\mathrm{O}_{3}$ and $\mathrm{OH}^{-}$during ozonation. The generation of $\mathrm{H}_{2} \mathrm{O}_{2}$ in the form of its conjugated base, $\mathrm{HO}_{2}^{-}$, is also observed during ozonation process (Eq. (11)). Produced $\mathrm{HO}_{2}^{-}$may then react with $\mathrm{O}_{3}$ to form $\mathrm{OH}^{\bullet}$ (Eq. (12)).

$$
\begin{gathered}
\mathrm{O}_{3}+\mathrm{OH}^{-}+\mathrm{e}^{-} \rightarrow \mathrm{HO}_{2}^{-}+\mathrm{O}_{2} \\
\mathrm{HO}_{2}^{-}+\mathrm{O}_{3} \rightarrow \mathrm{OH}^{\bullet}+\mathrm{O}_{2}^{--}+\mathrm{O}_{2}
\end{gathered}
$$

Therefore, in this case, PCT can be degraded either directly by $\mathrm{O}_{3}$ or indirectly by $\mathrm{OH}^{\bullet}$. Consequently, the kinetics of PCT degradation by ozonation can be expressed as follows:

$$
-\mathrm{d} \frac{[\mathrm{PCT}]}{\mathrm{dt}}=k_{O H} \cdot[\mathrm{PCT}]\left[\mathrm{OH}^{\bullet}\right]+k_{O_{3}}[\mathrm{PCT}]\left[\mathrm{O}_{3}\right]
$$



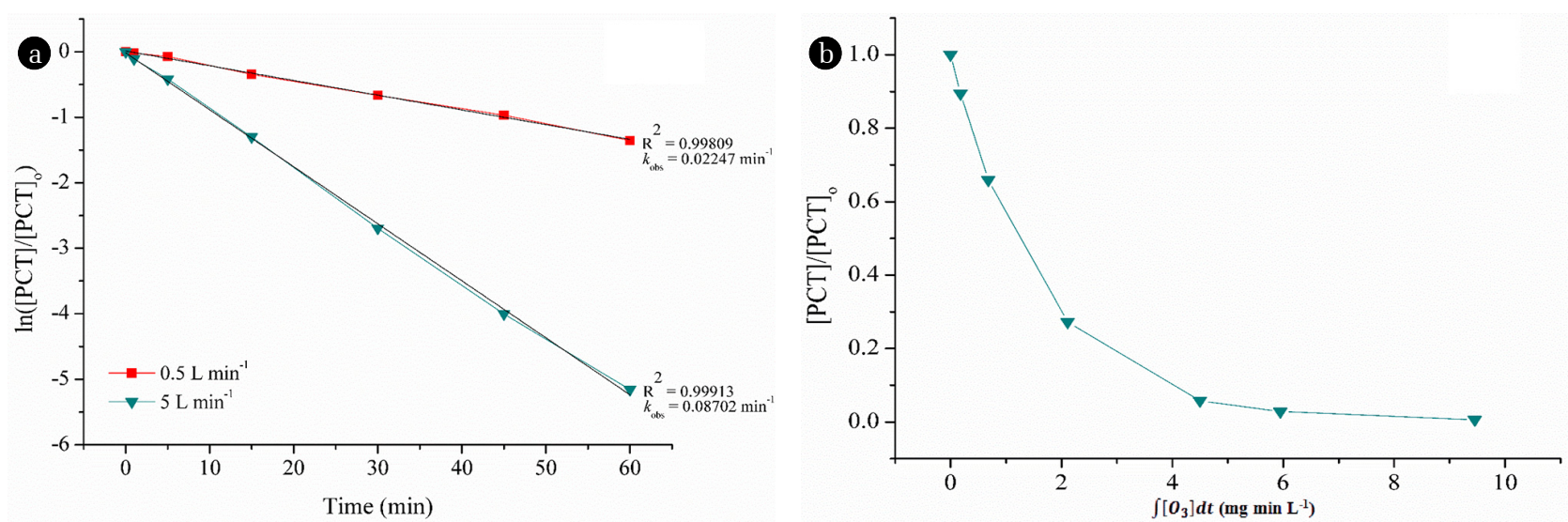

Fig. 3. Determination of reaction order for PCT degradation by ozonation: (a) A plot of $\ln [\mathrm{PCT}] /[\mathrm{PCT}]_{\mathrm{o}}$ vs. process time at two different $\mathrm{O}_{3}$ flow rates and pseudo-first-order kinetic constants $\left(k_{o b s,} \mathrm{~min}^{-1}\right)$ and (b) The effect of $\mathrm{O}_{3}$ exposure on the degradation of PCT. Reaction conditions: $[\mathrm{PCT}]_{\mathrm{o}}=100 \mathrm{mg} \mathrm{L}^{-1}$, initial $\mathrm{pH}=6.8 \pm 0.2, \mathrm{~T}=25^{\circ} \mathrm{C}$ and $\mathrm{O}_{3}$ flow rate: $5 \mathrm{~L}$ min- 1 .

The reaction kinetics has been calculated along with the $\mathrm{R}^{2}$ values (data not shown) and the degradation of PCT by ozonation process gave the highest $\mathrm{R}^{2}$ value when it was fitted only to the pseudo-first order rate law. The observed rate constants $\left(k_{\mathrm{obs}}\right)$ were given in Fig. 3(a) according to ozone flow rate.

$\mathrm{O}_{3}$ and $\mathrm{OH}^{\bullet}$ concentrations besides the corresponding rate constants are needed to predict PCT degradation by ozonation. $\mathrm{O}_{3}$ concentrations can be easily determined with standard methods. However, $\mathrm{OH}^{\bullet}$ concentrations are difficult to measure due to their very short half-life in waters. Then, the $R_{\mathrm{ct}}$ model in which the $R_{\mathrm{ct}}$ is determined by the ratio of $\mathrm{OH}^{\bullet}$ exposure to $\mathrm{O}_{3}$ exposure $\left(R_{\mathrm{ct}}=\int O H \cdot d t / \int O_{3} d t\right)$ can be used [34]. As stated by Elovitz and von Gunten [34], $R_{\mathrm{ct}}$ is constant in water for the duration of ozonation after early phases. Hence, $R_{\mathrm{ct}}$ can be written as the ratio of the $\left[\mathrm{OH}^{\bullet}\right]$ to the $\left[\mathrm{O}_{3}\right]$. So, $R_{\mathrm{ct}} \times \mathrm{O}_{3}$ is written instead of $\left[\mathrm{OH}^{\bullet}\right]$ in Eq. (13), then it yields Eq. (14):

$$
-\mathrm{d} \frac{[\mathrm{PCT}]}{\mathrm{dt}}=\left(k_{\mathrm{OH}} \times R_{c t}+k_{O_{3}}\right)[P C T]\left[O_{3}\right]
$$

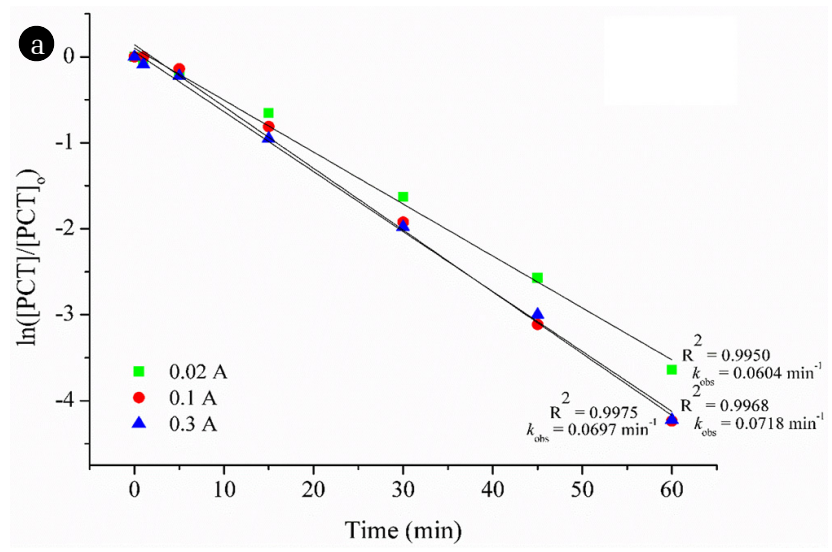

Fig. 4. Determination of reaction order for PCT degradation by E-peroxone: a plot of $\ln [\mathrm{PCT}] /[\mathrm{PCT}]_{\mathrm{o}}$ vs. process time (a) At different applied current values, (b) At different $\mathrm{O}_{3}$ flow rates and pseudo-first-order kinetic constants $\left(k_{\text {obs }}, \mathrm{min}^{-1}\right)$. Reaction conditions: $[\mathrm{PCT}]_{\mathrm{o}}=100 \mathrm{mg} \mathrm{L}^{-1}$, Applied current $(I)=0.3 \mathrm{~A}$ (for only $5 \mathrm{~b}$ ), initial $\mathrm{pH}=6.8 \pm 0.2, \mathrm{~T}=25^{\circ} \mathrm{C}$ and $\mathrm{O}_{3}$ flow rate: $0.5 \mathrm{~L}$ min- 1 (for only 5 a). 
to low solubility of $\mathrm{O}_{3}$. In other words, $\mathrm{OH}^{\bullet}$ formation would be limited by means of $\mathrm{O}_{3}$ transfer rate from gas to liquid phase as the current increases the critical value. Besides, $\mathrm{H}_{2} \mathrm{O}_{2}$ is known to be $\mathrm{OH}^{\bullet}$ scavenger. Thus, increasing applied current beyond a critical value may produce more $\mathrm{H}_{2} \mathrm{O}_{2}$ than needed, which can diminish the E-peroxone process efficiency [35, 36]. Consequently, the critical applied value was determined as 0.1 $\mathrm{A}$ in this case.

The effect of $\mathrm{O}_{3}$ flow rate has been investigated for E-peroxone degradation of PCT. As seen in Fig. 4(b), increasing $\mathrm{O}_{3}$ flow rate considerably increased the degradation rate of PCT. Complete removal was observed with $\mathrm{O}_{3}$ flow rate of $5 \mathrm{~L} \mathrm{~min}^{-1}$ at the applied current of $0.1 \mathrm{~A}$.

$\mathrm{OH}^{\bullet}$ is generated through the reaction between $\mathrm{O}_{3}$ and $\mathrm{H}_{2} \mathrm{O}_{2}$ during the E-peroxone process [37-39]. Therefore, the degradation of PCT depends on the concentrations of $\mathrm{O}_{3}, \mathrm{H}_{2} \mathrm{O}_{2}$ and $\mathrm{OH}^{\circ}$. However, $\mathrm{O}_{3}$ reacts with $\mathrm{H}_{2} \mathrm{O}_{2}$ only in the form of its conjugated base, $\mathrm{HO}_{2}^{-}$, and then the generation of $\mathrm{OH}^{\bullet}$ takes place:

$$
\begin{gathered}
\mathrm{H}_{2} \mathrm{O}_{2} \stackrel{k_{\mathrm{HO}_{2}-}}{\longrightarrow} \mathrm{H}^{+}+\mathrm{HO}_{2}^{-} \\
\mathrm{HO}_{2}^{-}+\mathrm{O}_{3} \stackrel{k_{\mathrm{HO}_{2}, O_{3}}}{\longrightarrow} \mathrm{OH}^{\bullet}+\mathrm{O}_{3}^{\bullet-}+\mathrm{O}_{2}
\end{gathered}
$$

The reaction kinetics have been considered by the highest $\mathrm{R}^{2}$ values (data not shown) for the degradation of PCT by E-peroxone process and the highest $\mathrm{R}^{2}$ value was obtained when it was fitted to the pseudo-first order rate law. $k_{\text {obs }}$ values were determined as 0.0718 and $0.1662 \mathrm{~min}^{-1}$ for $\mathrm{O}_{3}$ flow rates of 0.5 and $5 \mathrm{~L} \mathrm{~min}$, respectively at the applied current of $0.1 \mathrm{~A}$. In E-peroxone process, PCT is mostly degraded by $\mathrm{OH}^{\bullet}$ :

$$
-\mathrm{d} \frac{[\mathrm{PCT}]}{\mathrm{dt}}=k_{O H} \cdot[\mathrm{PCT}]\left[\mathrm{OH}^{\bullet}\right]
$$

Here, $k_{O H}\left[\mathrm{OH}^{\bullet}\right]$ indicates $k_{\mathrm{obs}}$ values. From a deeper point of view, $\mathrm{O}_{3}$ may also contribute the degradation of PCT, however, $\mathrm{O}_{3}$ reacts primarily with electro-generated $\mathrm{H}_{2} \mathrm{O}_{2}$ to produced $\mathrm{OH}^{\bullet}$. In this case, the kinetics of PCT degradation by E-peroxone can also be expressed as follows:

$$
-\mathrm{d} \frac{[\mathrm{PCT}]}{\mathrm{dt}}=k_{O H} \cdot[\mathrm{PCT}]\left[\mathrm{OH}^{\bullet}\right]+k_{O_{3}}[\mathrm{PCT}]\left[\mathrm{O}_{3}\right]
$$

Some amount of $\mathrm{O}_{3}$ is consumed according to the Eq. (17). Hence, $\mathrm{O}_{3}$ consumption also should be considered;

$$
-\mathrm{d} \frac{\left[\mathrm{O}_{3}\right]}{\mathrm{dt}}=k_{\mathrm{HO}_{2}{ }^{-}, \mathrm{O}_{3}}\left[\mathrm{HO}_{2}^{-}\right]\left[\mathrm{O}_{3}\right]
$$

Then Eq. (18) becomes Eq. (21):

$$
\begin{aligned}
-\mathrm{d} \frac{[\mathrm{PCT}]}{\mathrm{dt}}= & k_{\mathrm{OH} \cdot}[\mathrm{PCT}]\left[\mathrm{OH}^{\bullet}\right]+k_{\mathrm{O}_{3}}[\mathrm{PCT}]\left[\mathrm{O}_{3}\right]- \\
& k_{\mathrm{HO}{ }^{-}{ }^{-} \mathrm{O}_{3}}\left[\mathrm{HO}_{2}^{-}\right]\left[\mathrm{O}_{3}\right]
\end{aligned}
$$

\subsection{The Comparison of the Processes on the Degradation of PCT and Formation of Intermediates}

The degradation of commonly used analgesic PCT was evaluated by different AOPs in this study. In overall assessment, EOX, GEF, ozonation and E-peroxone processes were compared in terms of PCT degradation. All studied processes showed pseudo-first order reaction kinetic for PCT degradation. The conditions that gave maximum PCT removal for each process were determined and $k_{\text {obs }}$ values for those circumstances of EOX, GEF, ozonation and E-peroxone processes were 0.0022, 0.0029, 0.0870 and $0.1662 \mathrm{~min}^{-1}$, respectively (See Table 2). The order of the processes was E-peroxone $>$ ozonation $>$ GEF $>$ EOX for PCT degradation at their individual optimum conditions.

The complete degradation of PCT was observed in E-peroxone process. Due to the high rate constants at the E-peroxone and ozonation, PCT degradation would mostly take place by $\mathrm{OH}^{\bullet}$ and molecular $\mathrm{O}_{3}$. In contrast, with lower $k_{\text {obs }}$ values obtained in EOX process, hydroxyl radicals would not contribute considerably to the PCT degradation. There was almost no production $\mathrm{OH}^{\bullet}$ during EOX process in the bulk solution. Direct anodic oxidation via electron transfer on the electrode surface and produced $\mathrm{OH}^{\bullet}$ on the electrode surface $\left(\mathrm{Pt}\left(\mathrm{OH}^{\bullet}\right)\right)$ could be the main mechanism for EOX processes at Pt anode. In GEF process, relatively lower $k_{\text {obs }}$ values were also obtained comparing E-peroxone and ozonation processes. This was because of lower $\mathrm{OH}^{\bullet}$ production rates. However, GEF process provided slightly higher efficiency in PCT degradation than EOX process. This can be concluded that having an additional

Table 2. $k_{\text {obs }}$ Values Obtained in EOX, GEF, Ozonation and E-peroxone Processes. Reaction Conditions: $\mathrm{T}=25^{\circ} \mathrm{C}$, Initial $\mathrm{pH}=6.8$ \pm 0.2 (for EOX, Ozonation and E-peroxone), Applied Current $(I)=0.3 \mathrm{~A}$ (for GEF)

\begin{tabular}{lc}
\hline Process & $\boldsymbol{k}_{\text {obs }}\left(\mathbf{m i n}^{-1}\right)$ \\
\hline EOX & \\
$0.02 \mathrm{~A}$ & 0.00077 \\
$0.1 \mathrm{~A}$ & 0.00085 \\
$0.7 \mathrm{~A}$ & 0.00130 \\
$2 \mathrm{~A}$ & 0.00221 \\
\hline GEF & \\
pH 3.0 & 0.00290 \\
pH 6.8 & 0.00107 \\
pH 10 & 0.00170 \\
\hline Ozonation & \\
$0.5 \mathrm{~L} \mathrm{~min}^{-1}$ & 0.02247 \\
5 L min & \\
\hline E-peroxone & 0.08702 \\
$0.02 \mathrm{~A}$ & \\
$0.1 \mathrm{~A}$ & 0.06040 \\
$0.3 \mathrm{~A}$ & 0.06970 \\
$0.5 \mathrm{~L} \mathrm{~min}^{-1}$ & 0.07180 \\
5 L min & 0.07180 \\
\hline
\end{tabular}


source of oxidizing reagents provides more $\mathrm{OH}^{\bullet}$ production in the bulk solution. Besides, it should be noted that the applied current was $2 \mathrm{~A}$ in EOX process where it was $0.3 \mathrm{~A}$ in GEF process. It can be said that additional iron source to EOX process helps to reduce applied current and as well as energy consumption.

In Fig. $5, \mathrm{H}_{2} \mathrm{O}_{2}$ and $\mathrm{OH}^{\bullet}$ production capacities can be seen. Accordingly, $\mathrm{H}_{2} \mathrm{O}_{2}$ production increased during the time for GEF, ozonation and E-peroxone. Although the same electrodes (carbon-based cathode and Pt anode) were used in EOX process, negligible amount of $\mathrm{H}_{2} \mathrm{O}_{2}$ was produced. However, the addition of goethite in GEF process increased the amount of produced $\mathrm{H}_{2} \mathrm{O}_{2}$. It is known that $\mathrm{H}_{2} \mathrm{O}_{2}$ is produced at carbon-based cathode. However, the addition of iron source may contribute and increase the formation of $\mathrm{H}_{2} \mathrm{O}_{2}$ according to the following equations [19, 40]:

$$
\begin{aligned}
& \mathrm{Fe}^{2+}+\mathrm{HO}_{2}^{\cdot}+\mathrm{H}^{+} \rightarrow \mathrm{Fe}^{3+}+\mathrm{H}_{2} \mathrm{O}_{2} \\
& \mathrm{Fe}^{2+}+\mathrm{O}_{2}^{--}+2 \mathrm{H}^{+} \rightarrow \mathrm{Fe}^{3+}+\mathrm{H}_{2} \mathrm{O}_{2}
\end{aligned}
$$

The capacity of $\mathrm{H}_{2} \mathrm{O}_{2}$ production was extremely high at the end of time in ozonation and E-peroxone compared to GEF process. At $60 \mathrm{~min}$ of reaction time, 468.0, 2168.3, and $2675.0 \mathrm{mg} \mathrm{L}^{-1} \mathrm{H}_{2} \mathrm{O}_{2}$ was produced in GEF, ozonation and E-peroxone, respectively. However, $\mathrm{H}_{2} \mathrm{O}_{2}$ production rate was higher in the middle stages of GEF process compared to ozonation and E-peroxone. For instance, between 30-45 min of process time, while $\mathrm{H}_{2} \mathrm{O}_{2}$ concentration ranged between $200-344 \mathrm{mg} \mathrm{L}^{-1}$ for $\mathrm{EF}$, it ranged between $161.52-323 \mathrm{mg}$ $\mathrm{L}^{-1}$ and 183-190.6 $\mathrm{mg} \mathrm{L}^{-1}$ for ozonation and E-peroxone, respectively. This agrees with the above conclusion about less efficiency of the GEF process by means of excess $\mathrm{H}_{2} \mathrm{O}_{2}$ behaved as scavenger of $\mathrm{OH}^{\bullet}$. As it is seen from Fig. 5, when $\mathrm{H}_{2} \mathrm{O}_{2}$ production increased $\mathrm{OH}^{\bullet}$ formation decreased.

When $\mathrm{OH}^{\bullet}$ production capacity was compared, $\mathrm{OH}^{\bullet}$ formation increased until 10, 3 and 5 min of reaction time in GEF, ozonation and E-peroxone, respectively. Then, a decreasing trend was observed for all the processes. In EOX, $\mathrm{OH}^{\bullet}$ production was almost negligible comparing the other processes. Up to $0.87,23.32$, and $20.64 \mu \mathrm{M}$ of $\mathrm{OH}^{\bullet}$ concentrations were produced in GEF, ozonation and E-peroxone, respectively. Ozonation and E-peroxone processes provided much higher $\mathrm{OH}^{\bullet}$ production rates in contrast to GEF and EOX processes. This result agreed with the above conclusions.

Energy consumption should also be considered for the comparison of the processes. For this reason, specific energy consumption (SEC) values were calculated considering 50\% PCT removal percentage for each process according to the following equations:

$$
\begin{gathered}
\operatorname{SEC}_{\text {EOX, GEF }}\left(k W h \text { gPCT } \text { removed }^{-}\right)=\frac{\mathrm{U} \times \mathrm{i} \times \mathrm{t}}{\left([P C T]_{0}-[P C T]_{t}\right) \times V} \\
\mathrm{SEC}_{\text {Ozonation }}\left(k W h g_{P C T_{\text {removed }}}\right)=\frac{\mathrm{r} \times \mathrm{C}_{O 3}}{\left([P C T]_{0}-[P C T]_{t}\right) \times V} \\
\mathrm{SEC}_{E-\text { peroxone }}\left(k W h \text { gPCT }_{\text {removed }}{ }^{-}\right)=\frac{\mathrm{U} \times \mathrm{i} \times \mathrm{t}+\mathrm{r} \times C_{O 3}}{\left([P C T]_{0}-[P C T]_{t}\right) \times V}
\end{gathered}
$$

Where, $\mathrm{U}$ is the average voltage $(\mathrm{V})$ recorded during the processes, $i$ is the applied current (A), $\mathrm{t}$ is the process time (h), $[\mathrm{PCT}]_{0}$ and
$[\mathrm{PCT}]_{\mathrm{t}}$ represent the initial and treated PCT concentrations, respectively and $\mathrm{V}$ is the solution volume (L). $r$ is the energy need for ozone production (15 $\mathrm{kWh} \mathrm{kg}^{-1}$ ) [33], and $\mathrm{C}_{\mathrm{O} 3}$ is the amount of consumed ozone (g) which was calculated according to Eq. (24):
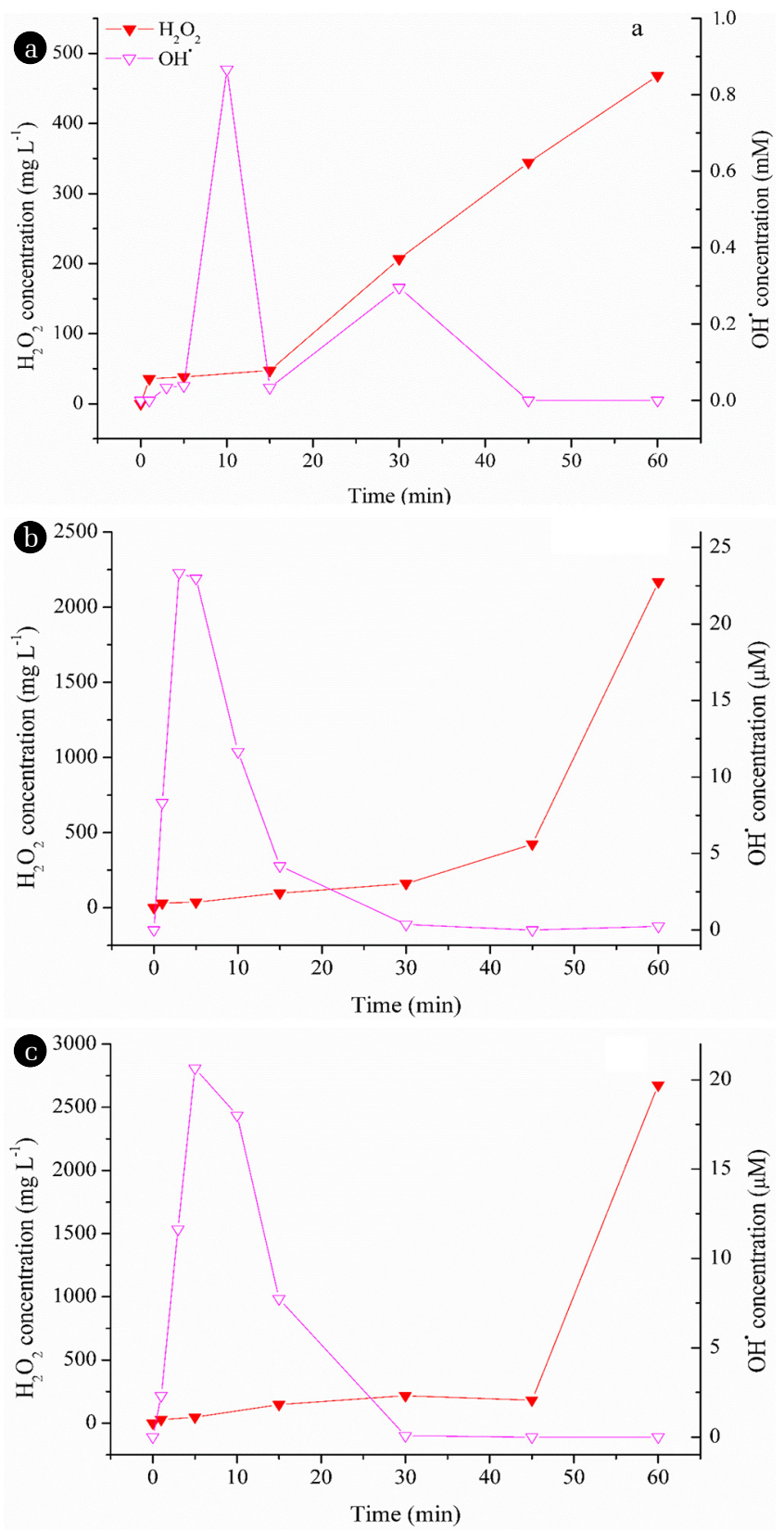

Fig. 5. $\mathrm{OH}^{\bullet}$ radical and $\mathrm{H}_{2} \mathrm{O}_{2}$ production capacities of (a) GEF, (b) Ozonation and (c) E-peroxone processes in TA and $\mathrm{Na}_{2} \mathrm{SO}_{4}$ solution, respectively. TA concentration $=2 \mathrm{mM}$ (for $\mathrm{OH}^{\bullet}$ measurement) and $\mathrm{Na}_{2} \mathrm{SO}_{4}$ concentration $=0.5 \mathrm{M}$ (for $\mathrm{H}_{2} \mathrm{O}_{2}$ measurement), Reaction conditions: initial $\mathrm{pH}=6.8 \pm 0.2, \mathrm{~T}=25^{\circ} \mathrm{C}$, Applied current $(I)=0.3 \mathrm{~A}$, and $\mathrm{O}_{3}$ flow rate: $5 \mathrm{~L} \mathrm{~min}^{-1}$ (for ozonation and E-peroxone), goethite concentration $=0.5 \mathrm{~g} \mathrm{~L}^{-1}$ (for EF). 


$$
C_{O 3}=Q_{g} \int_{0}^{t}\left[O_{3}\right]_{\text {inlet }} d t
$$

Where $\mathrm{Q}_{\mathrm{g}}$ is the gas flow rate $\left(\mathrm{L} \mathrm{min}^{-1}\right)$ and $\left[\mathrm{O}_{3}\right]_{\text {inlet }}$ is the inlet $\mathrm{O}_{3}$ concentration ( $\mathrm{mg} \mathrm{L}^{-1}$ ). The results and the conditions for each process can be found in supplementary material (Table SM-2). As seen from Table SM-2, SEC values were determined as 7.7844, 0.7158, 0.1452 and $0.1164 \mathrm{kWh}$ gPCT $_{\text {removed }}^{-1}$ for EOX, GEF, ozonation and E-peroxone, respectively. This suggests that ozonation and E-peroxone processes were cost effective compared to the other two processes. In conclusion, ozonation and E-peroxone processes were found to be more effective for PCT degradation considering process efficiency and energy consumption.

The formation of intermediates during each process is given in Fig. 6. As can be seen in Fig. 6 (a), only hydroquinone and catechol as aromatic compounds were identified during E-peroxone process indicating that hydroxyl radicals attacked in the aromatic ring of PCT. The concentration of hydroquinone was very low during the process and it almost disappeared at $30 \mathrm{~min}$ of process time. This suggests that the aromatics rapidly destroyed on the anode and were not accumulated in the medium. The degradation of PCT occurred via the formation of oxalic acid which come from the destruction of benzenic ring of aromatic compounds during E-peroxone process. During ozonation of PCT (see Fig. 6(b)), hydroquinone and benzoquinone were identified and they almost completely destroyed at $60 \mathrm{~min}$ and $15 \mathrm{~min}$ of process time, respectively. Final products were harmless carboxylic acids (oxalic acid and maleic acid). Oxalic acid concentration increased up to $45 \mathrm{~min}$ and then decreased, while maleic acid concentration increased until $15 \mathrm{~min}$ of process time and then decreased. During GEF process, aromatics (benzoquinone and hydroquinone) and oxalic acid formed (see Fig. 6(c)). The concentration of aromatics increased until $30 \mathrm{~min}$ of process time and then decreased. Aromatic compounds (benzoquinone, hydroquinone and catechol) and carboxylic acids (oxalic and maleic acids) were identified during EOX process (see Fig. 6(d)). However, the concentration of benzoquinone was very low during the EOX process and hydroquinone and catechol almost disappeared at $60 \mathrm{~min}$ and $30 \mathrm{~min}$ of process time, respectively. The final products were oxalic acid and maleic acid during the degradation of PCT by EOX process. As seen in Fig. 6, carboxylic acids (oxalic and/or maleic acid) were final products
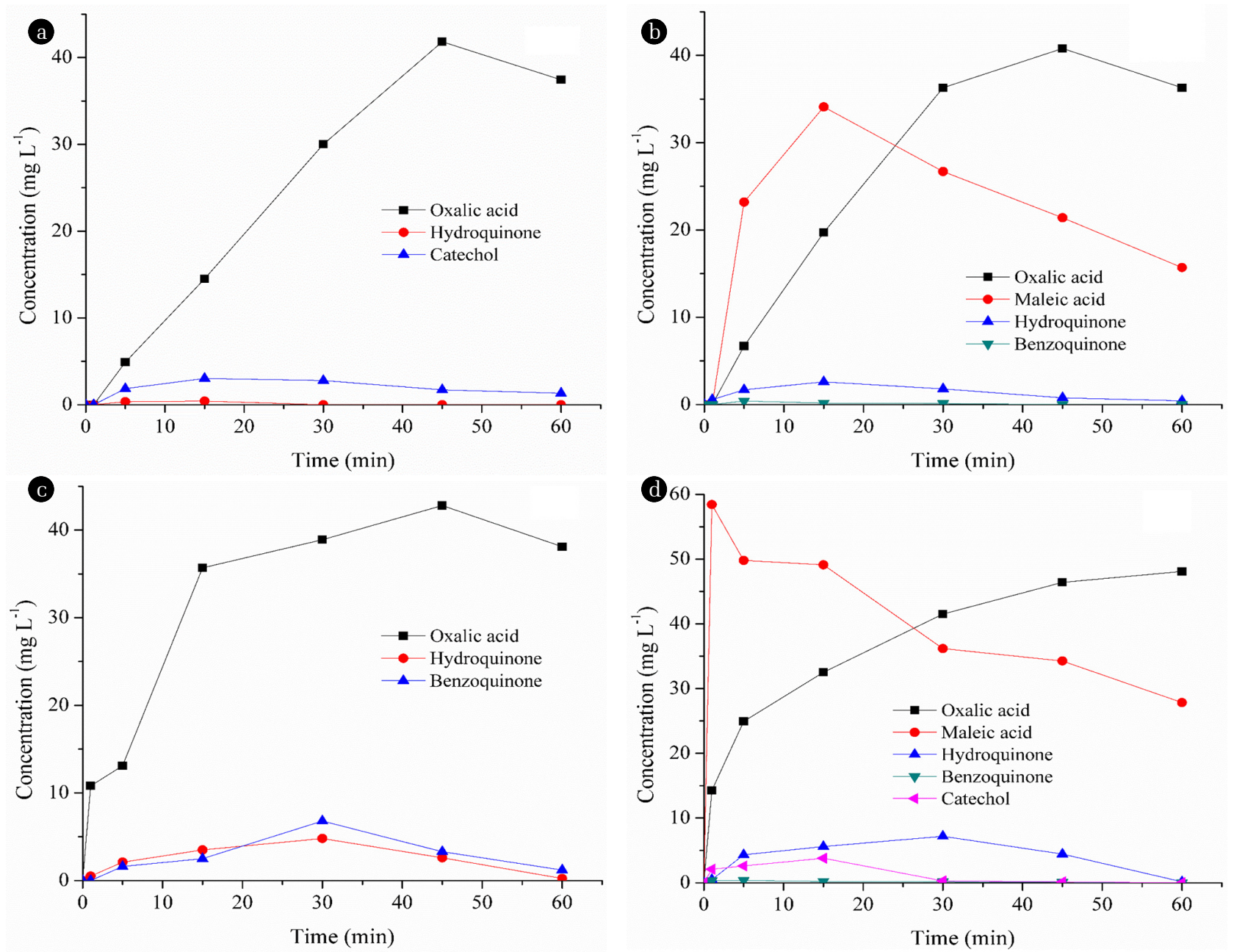

Fig. 6. The formation of intermediates during (a) E-peroxone, (b) Ozonation, (c) GEF and (d) EOX processes. 
for all processes during the degradation of PCT generated by ring cleavage and decarboxylation reaction which was reported by other researchers [41-43].

\section{Conclusions}

The degradation of PCT by EOX, GEF, ozonation and E-peroxone has been investigated in the present study. The higher and faster PCT degradation efficiencies were observed during E-peroxone and ozonation treatment. Kinetic studies showed that all processes were kindly fitted to pseudo-first order kinetic for PCT degradation. $k_{\text {obs }}$ values were determined as $0.00221,0.0017,0.0870$ and 0.1662 $\min ^{-1}$ for EOX, GEF, ozonation and E-peroxone processes, respectively. For GEF process, the adsorption part was controlled by diffusion. Where $\mathrm{OH}^{\bullet}$ production was almost negligible in EOX, up to $0.87,23.32$, and $20.64 \mu \mathrm{M} \mathrm{OH}^{\bullet}$ was generated in GEF, ozonation and E-peroxone, respectively. Ozonation and E-peroxone processes delivered considerably higher $\mathrm{OH}^{\bullet}$ production rates, contrary to GEF and EOX processes. When $k_{\mathrm{obs}}$ values of each process are compared, E-peroxone and ozonation processes which $\mathrm{O}_{3}$ is dominant, have much higher rate constants comparing EOX and GEF. Thus, it can be concluded that PCT degradation would mostly occurs through $\mathrm{OH}^{\bullet}$ and molecular $\mathrm{O}_{3}$. On the contrary, the EOX process with lower $k_{\text {obs }}$ values, hydroxyl radicals would not contribute noticeably to the PCT degradation. In the point of energy consumption, E-peroxone and ozonation were cost effective processes compared to EOX and GEF processes on PCT degradation. Aromatic compounds and carboxylic acids were identified as degradation intermediates during the processes and their concentration varied for each process. However, final by-products were carboxylic acids for all processes.

\section{Author Contributions}

H.Ö. (M. Sc.) performed the experiments and reported the results. S.B. (Ph.D.) drafted and wrote the manuscript, interpreted and evaluated the results, designed the experimental setup. Ö.T. (Ph.D.) assisted in data interpretation and helped in manuscript preparation.

\section{References}

1. Papageorgiou M, Kosma C, Lambropoulou D. Seasonal occurrence, removal, mass loading and environmental risk assessment of 55 pharmaceuticals and personal care products in a municipal wastewater treatment plant in Central Greece. Sci. Total Environ. 2016;543:547-569.

2. K'oreje K, Vergeynst L, Ombaka D, et al. Occurrence patterns of pharmaceutical residues in wastewater, surface water and groundwater of Nairobi and Kisumu city, Kenya. Chemosphere. 2016;149:238-244.

3. Vymazal J, Březinová TD, Koželuh M, Kule L. Occurrence and removal of pharmaceuticals in four full-scale constructed wet- lands in the Czech Republic-the first year of monitoring. Ecol. Eng. 2017;98:354-364.

4. Alygizakis NA, Gago-Ferrero P, Borova VL, Pavlidou A, Hatzianestis I, Thomaidis NS. Occurrence and spatial distribution of 158 pharmaceuticals, drugs of abuse and related metabolites in offshore seawater. Sci. Total Environ. 2016;541: 1097-1105.

5. Mathon B, Choubert J-M, Miege C, Coquery M. A review of the photodegradability and transformation products of 13 pharmaceuticals and pesticides relevant to sewage polishing treatment. Sci. Total Environ. 2016;551:712-724.

6. Russo D, Spasiano D, Vaccaro M, et al. Investigation on the removal of the major cocaine metabolite (benzoylecgonine) in water matrices by $\mathrm{UV}_{254} / \mathrm{H}_{2} \mathrm{O}_{2}$ process by using a flow microcapillary film array photoreactor as an efficient experimental tool. Water Res. 2016;89:375-383.

7. Togola A, Budzinski H. Multi-residue analysis of pharmaceutical compounds in aqueous samples. J. Chromatogr. A. 2008;1177:150-158.

8. Baresel C, Malmborg J, Ek M, Sehlén R. Removal of pharmaceutical residues using ozonation as intermediate process step at Linköping WWTP, Sweden. Water Sci. Technol. 2016;73: 2017-2024.

9. Nakada N, Shinohara H, Murata A, et al. Removal of selected pharmaceuticals and personal care products (PPCPs) and endocrine-disrupting chemicals (EDCs) during sand filtration and ozonation at a municipal sewage treatment plant. Water Res. 2007;41:4373-4382.

10. Shirafkan A, Nowee S, Ramezanian N, Etemadi MM. Hybrid coagulation/ozonation treatment of pharmaceutical wastewater using ferric chloride, polyaluminum chloride and ozone. Int. J. Environ. Sci. Technol. 2016;13:1443-1452.

11. Liu P, Zhang H, Feng Y, Yang F, Zhang J. Removal of trace antibiotics from wastewater: a systematic study of nanofiltration combined with ozone-based advanced oxidation processes. Chem. Eng. J. 2014;240:211-220.

12. Barışçı S, Ulu F, Sillanpää M, Dimoglo A. Evaluation of flurbiprofen removal from aqueous solution by electrosynthesized ferrate (VI) ion and electrocoagulation process. Chem. Eng. J. 2015;262:1218-1225.

13. Barışçı S, Ulu F, Sillanpää M, Dimoglo A. The usage of different forms of ferrate (VI) ion for amoxicillin and ciprofloxacin removal: density functional theory based modelling of redox decomposition. J. Chem. Technol. Biot. 2015.

14. Das L, Barodia S, Sengupta S, Basu J. Aqueous degradation kinetics of pharmaceutical drug diclofenac by photocatalysis using nanostructured titania-zirconia composite catalyst. Int. J. Environ. Sci. Technol. 2015;12:317-326.

15. Bolton JR, Bircher KG, Tumas W, Tolman CA. Figures-of-merit for the technical development and application of advanced oxidation processes. J. Adv. Oxid. Technol. 1996;1:13-17.

16. Bolton JR, Valladares JE, Zanin JP, et al. Figures-of-merit for Advanced Oxidation Technologies: a comparison of homogeneous $\mathrm{UV} / \mathrm{H}_{2} \mathrm{O}_{2}$, heterogeneous $\mathrm{UV} / \mathrm{TiO}_{2}$ and electron beam processes. J. Adv. Oxid. Technol. 1998;3:174-181.

17. Brillas E, Thiam A, Garcia-Segura S. Incineration of acidic aqueous solutions of dopamine by electrochemical advanced oxida- 
tion processes with Pt and BDD anodes. J. Electroanal. Chem. 2016;775:189-197.

18. Lan Y, Coetsier C, Causserand C, Serrano KG. On the role of salts for the treatment of wastewaters containing pharmaceuticals by electrochemical oxidation using a boron doped diamond anode. Electrochim. Acta. 2017;231:309-318.

19. Oturan MA, Aaron J-J. Advanced Oxidation Processes in Water/Wastewater Treatment: Principles and Applications. A Review. Crit. Rev. Environ. Sci. Technol. 2014;44:2577-2641.

20. Pimentel M, Oturan N, Dezotti M, Oturan MA. Phenol degradation by advanced electrochemical oxidation process electro-Fenton using a carbon felt cathode. Appl. Catal. B Environ. 2008;83:140-149.

21. Wei X, Wu H, He G, Guan Y. Efficient degradation of phenol using iron-montmorillonite as a Fenton catalyst: Importance of visible light irradiation and intermediates. J. Hazard. Mater. 2017;321:408-416.

22. Sopaj F, Oturan N, Pinson J, Podvorica F, Oturan MA. Effect of the anode materials on the efficiency of the electro-Fenton process for the mineralization of the antibiotic sulfamethazine. Appl. Catal. B Environ. 2016;199:331-341.

23. Le TXH, Charmette C, Bechelany M, Cretin M. Facile preparation of porous carbon cathode to eliminate paracetamol in aqueous medium using electro-fenton system. Electrochim. Acta. 2016;188:378-384.

24. Turkay O, Ersoy ZG, Barışçı S. Review-The Application of an Electro-Peroxone Process in Water and Wastewater Treatment. J. Electrochem. Soc. 2017a;164:E94-E102.

25. Milan-Segovia N, Wang Y, Cannon FS, Voigt RC, Furness JC. Comparison of hydroxyl radical generation for various advanced oxidation combinations as applied to foundries. Ozone Sci. Eng. 2007;29:461-471.

26. Ahmadzadeh S, Dolatabadi M. Removal of acetaminophen from hospital wastewater using electro-Fenton process. Environ. Earth Sci. 2018;53:1-11.

27. Almeida LC, Garcia-Segura S, Bocchi N, Brillas E. Solar photoelectro-Fenton degradation of paracetamol using a flow plant with a Pt/air-diffusion cell coupled with a compound parabolic collector: Process optimization by response surface methodology. Appl. Catal. B Environ. 2011; 103: 21-30.

28. Ting WP, Lu MC, Huang YH. Kinetics of 2, 6-dimethylaniline degradation by electro-Fenton process. J. Hazard. Mater. 2009;161:1484-1490.

29. Kurt U, Apaydin O, Gonullu MT. Reduction of COD in wastewater from an organized tannery industrial region by
Electro-Fenton process. J. Hazard. Mater. 2007;143:33-40.

30. Liu H, Li X, Leng Y, Wang C. Kinetic modeling of electro-Fenton reaction in aqueous solution. Water Res. 2007;41:1161-1167.

31. Mousset E, Frunzo L, Esposito G, Van Hullebusch ED, Oturan N, Oturan MA. A complete phenol oxidation pathway obtained during electro-Fenton treatment and validated by a kinetic model study. Appl. Catal. B Environ. 2016;180:189-198.

32. Neyens E, Baeyens J. A review of classic Fenton's peroxidation as an advanced oxidation technique. J. Hazard. Mater. 2003;98: 33-50.

33. Duesterberg CK, Waite TD. Process optimization of Fenton oxidation using kinetic modeling. Environ. Sci. Technol. 2006;40: 4189-4195.

34. Elovitz MS, von Gunten U. Hydroxyl radical/ozone ratios during ozonation processes. I. The Rct Concept. 1999.

35. Li X, Wang Y, Zhao J, Wang H, Wang B, Huang J, Deng S, Yu G. Electro-peroxone treatment of the antidepressant venlafaxine: Operational parameters and mechanism. J. Hazard. Mater. 2015;300:298-306.

36. Yao W, Wang X, Yang H, et al. Removal of pharmaceuticals from secondary effluents by an electro-peroxone process. Water Res. 2016;88:826-835.

37. Bakheet B, Yuan S, Li Z, et al. Electro-peroxone treatment of Orange II dye wastewater. Water Res. 2013;47:6234-6243.

38. Li X, Wang Y, Yuan S, et al. Degradation of the anti-inflammatory drug ibuprofen by electro-peroxone process. Water Res. 2014;63:81-93.

39. Wang H, Bakheet B, Yuan S, et al. Kinetics and energy efficiency for the degradation of 1, 4-dioxane by electro-peroxone process. J. Hazard. Mater. 2015;294:90-98.

40. Brillas E, Sirés I, Oturan MA. Electro-Fenton Process and Related Electrochemical Technologies Based on Fenton's Reaction Chemistry. Chem. Rev. 2009;109:6570-6631.

41. He Y, Wang X, Huang W, et al. Hydrophobic networked $\mathrm{PbO}_{2}$ electrode for electrochemical oxidation of paracetamol drug and degradation mechanism kinetics. Chemosphere 2018;193: 89-99.

42. Luna MD, Veciana M, Su C, Lu M. Acetominophen degradation by electro-Fenton and photoelectro-Fenton using a double cathode electrochemical cell. J. Hazard. Mater. 2012;217-218: 200-207.

43. Arredondo VHC, García JG, Gutiérrez GS, Ponce de León C. Degradation of paracetamol by advanced oxidation processes using modified reticulated vitreous carbon electrodes with $\mathrm{TiO}_{2}$ and $\mathrm{CuO} / \mathrm{TiO}_{2} / \mathrm{Al}_{2} \mathrm{O}_{3}$. Chemosphere 2012;89:1185-1201. 